\title{
Drying of fibrous roots strengthens the negative power relation between biomechanical properties and diameter
}

\author{
E. C. Ekeoma • D. Boldrin $\mathbb{D} \cdot$ K. W. Loades $\cdot$ \\ A. G. Bengough
}

Received: 22 April 2021 / Accepted: 7 September 2021 / Published online: 4 October 2021

(C) The Author(s) 2021

\begin{abstract}
Aims Test the effects of root drying on biomechanical properties of fibrous roots.

Methods Tensile strength and Young's modulus of Festuca arundinacea roots were tested after full hydration and during progressive drying. Root diameter, water loss, and water content were measured for all treatments.

Results Hydrated roots showed weak relations between biomechanical properties and diameter. After only 30 min air-drying, both tensile strength and Young's modulus increased significantly in thin roots $(<1 \mathrm{~mm})$ and after $60 \mathrm{~min}$ drying, both strength and Young's modulus showed a negative power relation with root diameter. The maximum strength and Young's modulus values recorded after $60 \mathrm{~min}$ drying were respectively three- and four-times greater than in hydrated roots. Strength and Young's modulus
\end{abstract}

Responsible Editor: Alexia Stokes

Supplementary Information The online version contains supplementary material available at https://doi. org/10.1007/s11104-021-05150-1.

E. C. Ekeoma · D. Boldrin · A. G. Bengough

School of Science and Engineering, University of Dundee, Dundee DD2 5DA, UK

D. Boldrin $(\varangle) \cdot$ K. W. Loades · A. G. Bengough

The James Hutton Institute, Invergowrie,

Dundee DD2 5DA, UK

e-mail: d.z.boldrin@dundee.ac.uk increased rapidly when water content dropped below $0.70 \mathrm{~g} \mathrm{~g}^{-1}$. These biomechanical changes were the result of root diameter shrinkage of up to $50 \%$ after 60 min drying, driven by water loss of up to $0.7 \mathrm{~g} \mathrm{~g}^{-1}$. Conclusions Strength and Young's modulus largely increased with root drying. We suggest controlling root moisture and testing fully hydrated roots as standard protocol, given that slope instability is generally caused by heavy rainfall events and loss of matric suction.

Keywords Fibrous roots $\cdot$ Root diameter $\cdot$ Root moisture $\cdot$ Soil bioengineering $\cdot$ Tensile strength . Young's modulus

\section{Introduction}

The use of vegetation in soil-bioengineering is recognized as an environmentally sustainable solution for slope stabilization (Ghestem et al. 2014; Kim et al. 2017). Roots can provide mechanical reinforcement, anchoring the soil mass and creating a composite material, with enhanced mechanical properties (e.g., resistance in tension; Docker and Hubble, 2008). Plant ability to stabilize soil on slopes varies between species and functional types with fibrous roots of grasses being more effective in creating a root-soil composite material, similar to fiber-reinforced soil, and hence preventing erosion and shallow failures (Norris et al. 2008). Indeed, 
fibrous roots have the capacity to mobilize more cohesion then tap roots for the same root area ratio (De Baets et al. 2008).

Prediction of root derived mechanical reinforcement relies on robust empirical data including root biomechanical properties (Bischetti et al. 2009; Schwarz et al. 2016). Root tensile strength and Young's modulus are the most widely studied biomechanical traits in relation to soil bioengineering (Bischetti et al. 2005; Mao et al. 2012) and are common model inputs to predict root mechanical reinforcement and slope stability (Schwarz et al. 2013; Wu et al. 1979).

Root biomechanical properties are obtained by laboratory or field tensile testing with root segments clamped and stretched at a fixed rate until failure occurs (Boldrin et al. 2021; Giadrossich et al. 2017). Currently there is no universally adopted protocol for the measurement of root mechanical properties with approaches varying in terms of sample preparation, root storage prior to testing, sample length, extension rate, and measurement devices (Giadrossich et al. 2017; Hales et al. 2009). For example, Bischetti et al. (2005) compared three different methods to store roots before tensile testing ((i) drying roots at $60{ }^{\circ} \mathrm{C}$ for $24 \mathrm{~h}$ and rewetting them in water for a few hours, (ii) freezing roots in a plastic bag filled with water and (iii) storing in $15 \%$ alcohol solution) with no significant effect on root tensile strength reported. However, root drying and rewetting, affected biomechanical properties in Hales et al. (2013) study. Neither study by Bischetti et al. (2005) or Hales et al. (2013) on both storage and root drying/rewetting measured the Young's Modulus of root tissue.

Root biomechanical properties can be affected by root diameter (De Baets et al. 2008; Mao et al. 2012; Stokes et al. 2009), water content (Boldrin et al. 2018; Hales and Miniat, 2017), chemical composition (Genet et al. 2005), root age (Loades et al. 2015), topological order (Mao et al. 2018), anatomy (Mao et al. 2018) and growth conditions (Loades et al. 2013).

The relations between tensile strength and root diameter have been presented for almost all species tested in bioengineering studies (Bischetti et al. 2005; De Baets et al. 2008; Mao et al. 2012). A negative power law model (Eq. 1) has generally been used to model these relations, where root tensile strength $\left(T_{r}\right)$ decreases exponentially with root diameter $(d)$ increase (De Baets et al. 2008; Mao et al. 2012).
$T_{r}=\alpha d^{-\beta}$

In this model, $\alpha$ and $\beta$ are empirical coefficients which are species specific. While $\alpha$ is the scale factor, $\beta$ controls the rate of strength decay with $d$ increase. For instance, De Baets et al. (2008) presented the negative power law fitting of tensile strength-diameter relations for 25 Mediterranean species, including grasses, forbs and shrubs.

In addition to root tensile strength, Young's modulus (i.e., material stiffness) of roots may also contribute to soil shear strength controlling the mobilization of root reinforcement during soil deformation (Schwarz et al. 2010). Generally, stiffer roots can provide greater soil reinforcement (Ghestem et al. 2014). However, fewer studies have reported relationships between Young's modulus and root diameter compared to the widely reported relation between root tensile strength and diameter (Mao et al. 2012). Most of these studies fitted the modulus-diameter relation using a negative power law model (Fan and $\mathrm{Su}$, 2008; Jotisankasa and Taworn, 2016; Mickovski et al. 2009).

Despite the common use of the negative power model to fit biomechanical vs diameter data, this model generally explains only a small part of observed variability. For instance, Liang et al. (2017) found that the negative power function poorly predicted biomechanical properties of roots sampled from young plants of three contrasting species (i.e., woody and grass species). Other studies on woody roots have also challenged the general assumption of negative power law between diameter and biomechanical properties (Boldrin et al. 2017, 2018; Hales and Miniat, 2017; Mao et al. 2018).

A review by Giadrossich et al. (2017) listed root water content as an important sample variable during biomechanical testing. However, the water content of the roots before, during, and after testing is rarely reported in most studies on root biomechanical properties. Few studies, mainly those for woody roots of trees and shrubs, have investigated the effect of root moisture (Hales and Miniat 2017; Yang et al. 2016; Boldrin et al. 2018). A recent study by Boldrin et al. (2018) found that a large increase in strength and stiffness of thin woody roots upon air-drying ( $>5 \mathrm{~h}$ ) can result in a negative power relation between root biomechanical properties and diameter (Boldrin et al. 2018). Although the effect of water content on root 
biomechanical properties would be expected to be greater in soft non-woody roots, this has been rarely investigated. A recent study by Zhang et al. (2019) assessed the effect of moisture on biomechanical properties of herbaceous roots dried for 6 and $12 \mathrm{~h}$ suggesting a root strengthening. However, to our knowledge, no study has yet investigated the drying effect in fibrous roots during short time periods such as those potentially experienced during laboratory root handling and testing. Therefore, there is a need to understand the influence of short drying periods during root mechanical testing on empirically measured root biomechanics. The following research questions will be addressed: (i) Can short periods of root drying increase tensile strength and Young's modulus in fibrous roots? (ii) What is the mechanism involved in the change of biomechanical properties upon drying? (iii) Can root drying enhance the negative power relation between diameter and biomechanical properties? Fibrous roots of the wide-spread grass Festuca arundinacea were tested to answer these questions.

\section{Materials and method}

\section{Root sampling}

Festuca arundinacea (Common name: Tall Fescue; Family: Poaceae) was selected as the model species in this study. Festuca arundinacea is a perennial grass commonly found in Europe, Asia, and North Africa (Gibson and Newman, 2001). Tall Fescue was selected due to its potential application for shallow slope stabilization, erosion control, environmental restoration and phytoremediation (Reinbott and Blevins, 1995; Dong et al. 2019; Khashij et al. 2018). In particular, Festuca arundinacea has been recently tested for biomechanical properties (Boldrin et al. 2021) and suggested for stabilization of pathways and terraces in vineyards (Norris et al. 2008).

In May 2019, Festuca arundinacea roots were sampled from Bungalow field at The James Hutton Institute, Dundee (UK; latitude 56 $27^{\circ} 26^{\prime \prime} \mathrm{N}$, longitude $\left.3^{\circ} 4^{\prime} 17^{\prime \prime} \mathrm{W}\right)$. The roots were carefully sampled from the topsoil ( $\approx 250 \mathrm{~mm}$ depth). Sampled roots were washed from soil using water and a range of sieves with mesh apertures from 2 to $0.5 \mathrm{~mm}$. After washing, roots were cut into $60 \mathrm{~mm}$ long segments for mechanical testing with roots showing evidence of damage were discarded. Each root segment was fully hydrated in distilled water for $24 \mathrm{~h}$ and stored in moist blotting tissues at $5{ }^{\circ} \mathrm{C}$ prior to testing. All roots were mechanically tested within $48 \mathrm{~h}$ of sampling to minimize potential influence of root decay.

\section{Root drying treatments}

A preliminary pilot test was carried out to determine the effect of complete root de-hydration on root biomechanical properties. Ten root segments of similar diameter were randomly selected for this pilot test (Suppl. Table 1). Five root segments were oven-dried at $75^{\circ} \mathrm{C}$ for $24 \mathrm{~h}$, while the remaining five roots were fully hydrated in water for $24 \mathrm{~h}$. Root diameter was determined as the mean of 3 diameter measurements distributed uniformly along the root segment axis (10 mm, $30 \mathrm{~mm}$, and $50 \mathrm{~mm})$. Measurements were performed using a stereo microscope and a graticule at $10 \times$ magnification (Leica, Milton Keynes, United Kingdom). Root diameters for oven-dried segments were recorded before and after the oven-drying to quantify drying effects on root diameter. Root tensile strength and Young's modulus were measured for both hydrated and oven-dried roots and calculated with diameter recorded immediately before testing (e.g., after oven-drying; see Biomechanical properties of the roots section).

Following the pilot test, representing an extreme condition of root drying (i.e., complete de-hydration of material), three air-drying time periods (treatments) were selected for this study: time 0 (i.e., fully hydrated roots), $30 \mathrm{~min}$, and $60 \mathrm{~min}$. Sixty root segments $(60 \mathrm{~mm}$ length) were randomly selected from the washed-out root population and 20 tested for each treatment (i.e., 20 hydrated roots, 20 roots air-dried for $30 \mathrm{~min}$, and 20 roots air-dried for $60 \mathrm{~min}$ ). In the case of any slippage, tensile test was discarded (see Biomechanical properties of the roots section and Table 1).

During air-drying, root segments were placed on a flat plastic tray within a temperature-controlled laboratory $\left(19{ }^{\circ} \mathrm{C} \pm 0.03\right.$; relative humidity $\left.\approx 50 \%\right)$. The diameter and weight of the roots before (i.e., hydrated root), and after drying treatments were applied, was recorded. The weight of the root segments was measured using a four-decimal place balance $( \pm 0.0001 \mathrm{~g})$. 
Water loss $\left(w_{L} ; \mathrm{g} \mathrm{g}^{-1}\right)$ from the roots was calculated using Eq. (2).

$w_{L}=\left(\frac{M_{\text {hyd }}-M_{t}}{M_{\text {hyd }}}\right)$

where $M_{h y d}$ and $M_{t}$ are the weight of the hydrated root segment $(\mathrm{g})$ and the weight of the root segment $(\mathrm{g})$ after the drying treatment, respectively. Water loss $\left(w_{L}\right)$ is reported as water per root hydrated weight (i.e., initial weight before air-drying treatment). To limit the time interval between drying treatment being applied and root mechanical testing, sample drying treatments were staggered into groups of three. Roots that were ready to be mechanically tested were covered with a plastic film and sealed in a plastic bag to prevent further water loss following prescribed time of drying. After the biomechanical testing root segments were dried at $75^{\circ} \mathrm{C}$ until a constant weight was reached. Root water content $\left(w_{c} ; \mathrm{g} \mathrm{g}^{-1}\right)$ was calculated using Eq. (3).

$w_{c}=\left(\frac{M_{t}-M_{d}}{M_{t}}\right)$

where $M_{\mathrm{t}}$ and $M_{d}$ are the weight of the fresh root after the drying treatment $(\mathrm{g})$ and weight of the oven-dried sample, respectively.

Biomechanical properties of the roots

Tensile testing of the roots was performed using a universal testing machine (Instron 5966, Norwood, MA, USA) with $500 \mathrm{~N}$ load cell $( \pm 0.125 \mathrm{~N}$ accuracy) and an extension rate of $2 \mathrm{~mm} \mathrm{~min}^{-1}$ (Genet et al. 2005). Root segments were clamped using pneumatic side action clamps (Instron 2712 series) with $100 \mathrm{kPa}$ confining pressure to ensure consistent clamping pressure between samples. Confining pressure was chosen based on preliminary tensile tests of $F$. arundinacea roots using different confining pressures. The selected $100 \mathrm{kPa}$ confining pressure was able to stop root slippage while limiting root damage and failure within clamps (Suppl. Fig. 1). The length of the root segment between the clamps was $35 \mathrm{~mm}$. In the case of any slippage, tensile test was discarded.

Tensile strength (MPa) at maximum load and Young's modulus (MPa) were obtained from the stress-strain curve of the tested sample (Loades et al.,
2013). The tensile strength $\left(T_{r}\right)$ at maximum load was calculated using Eq. (4).

$T_{r}=\frac{F}{\pi\left(\frac{d^{2}}{4}\right)}$

where $F$ is the maximum force $(\mathrm{N})$ required to break the root and $d$ is the root diameter (mm). Young's modulus $\left(E_{r}\right)$ was calculated from the initial gradient of the stress-strain curve within the elastic region (i.e., initial linear region):

$E_{r}=\frac{F L_{o}}{\pi\left(\frac{d^{2}}{4}\right) \Delta l}$

where $F$ is the applied force $(\mathrm{N}) ; L_{o}$ is the initial length ( $\mathrm{mm}$ ) of the root sample (i.e., $35 \mathrm{~mm}$ ); and $\Delta L$ is the change in root length ( $\mathrm{mm}$ ) during tensioning. The root tensile strength and Young's modulus were calculated using both the hydrated root diameter (i.e., initial root diameter before treatment) and the root diameter after drying (i.e., final root diameter after air-drying treatment).

The relation between surface area $\left(\mathrm{mm}^{2}\right)$ and volume $\left(\mathrm{mm}^{3}\right)$ of each root segment was calculated from the initial diameter (i.e., hydrated diameter before treatment) and the segment length $\left(L_{s} ; 60 \mathrm{~mm}\right)$, assuming a cylindrical shape (Eq. 6).

$\frac{A}{V}=\frac{\pi d L_{s}+\left(\pi\left(\frac{d}{2}\right)^{2}\right) * 2}{\pi(d / 2)^{2} L_{s}}$

Statistical analysis

The statistical analysis was performed using GenStat 17th (VSN International), SPSS Version 24 (IBM Corp) and SigmaPlot 14 (Systat Software, San Jose, $\mathrm{CA})$. The variability in the averaged result is presented as \pm standard error of the mean (SE). Significant difference between treatments were tested using one way-ANOVA, followed by post hoc Tukey's test. Data that did not follow a normal distribution were log-transformed prior to ANOVA (for details see Results section and figure captions). The results were considered statistically significant when $\mathrm{p}$ value $<0.05$. 


\section{Results}

\section{Root biomechanical properties}

Stress-strain curves of the hydrated roots highlighted the typical bi-phasic nature of elastic-plastic materials (Boldrin et al. 2018; Yang et al. 2016; Loades et al. 2013). Initial preliminary testing (pilot test) highlighted that oven-dried roots showed a steeper stress-strain curve (Fig. 1), with reduced strain to failure $(<10 \%$ strain) when compared to hydrated roots (strain to failure $>20 \%$ ). The stress-strain curve of hydrated roots also showed a larger plastic deformation region than elastic deformation during tensile testing. In contrast, elastic deformation dominated in the stress-strain curves of oven-dried roots. Hence, the hydrated roots were ductile while the oven-dried roots were brittle. A maximum tensile strength of $9.8 \mathrm{MPa}$ (mean $=5.07 \pm 1.26 \mathrm{MPa}$ ) was recorded in hydrated roots and $61.54 \mathrm{MPa}$ (mean $=39.8 \pm 7.34 \mathrm{MPa})$ in oven-dried roots. Maximum values of Young's modulus were 150.3 MPa (mean $=69.03 \pm 22.86 \mathrm{MPa}$ ) in hydrated roots and $1426.69 \mathrm{MPa} \quad($ mean $=999.52 \pm 120.04 \mathrm{MPa})$ in oven-dried roots. Observations during tensile testing showed some instances of root cortex failing before the stele. This explains the intermediate stress drops observed in two of the stress-strain curves (Fig. 1).

To understand the potential effect of root drying over short periods under laboratory conditions (e.g., during common material handling and testing), root biomechanical properties for fully hydrated (time 0 ; initial d 1.09-1.68 mm) and air-dried roots for $30 \mathrm{~min}$ (initial d: $1.1-1.76 \mathrm{~mm}$ ) and $60 \mathrm{~min}$ (initial d: $1.0-1.95 \mathrm{~mm}$ ) were tested and the results are shown in Fig. 2. Unlike the oven-dried roots, which had a maximum strain of $0.13 \mathrm{~mm} \mathrm{~mm}^{-1}$ (mean $=0.08 \pm 0.03 \mathrm{~mm} \mathrm{~mm}^{-1}$ ), air-dried roots showed larger strain values, with a maximum of $0.42 \mathrm{~mm} \mathrm{~mm}{ }^{-1}\left(\right.$ mean $\left.=0.30 \pm 0.01 \mathrm{~mm} \mathrm{~mm}^{-1}\right)$ and $0.39 \mathrm{~mm} \mathrm{~mm}^{-1}\left(\right.$ mean $\left.=0.33 \pm 0.01 \mathrm{~mm} \mathrm{~mm}^{-1}\right)$ for the $30 \mathrm{~min}$ and $60 \mathrm{~min}$ treatments respectively (Table 1). There were no significant differences between the mean of the tensile strain of the hydrated root (time 0 ) and the air-dried roots ( $\mathrm{p}$ value $=0.18)$.

Maximum tensile strength and Young's modulus values observed in hydrated roots (i.e., time 0) was $10.29 \mathrm{MPa}($ mean $=5.81 \pm 0.41 \mathrm{MPa})$ and $82.77 \mathrm{MPa}$

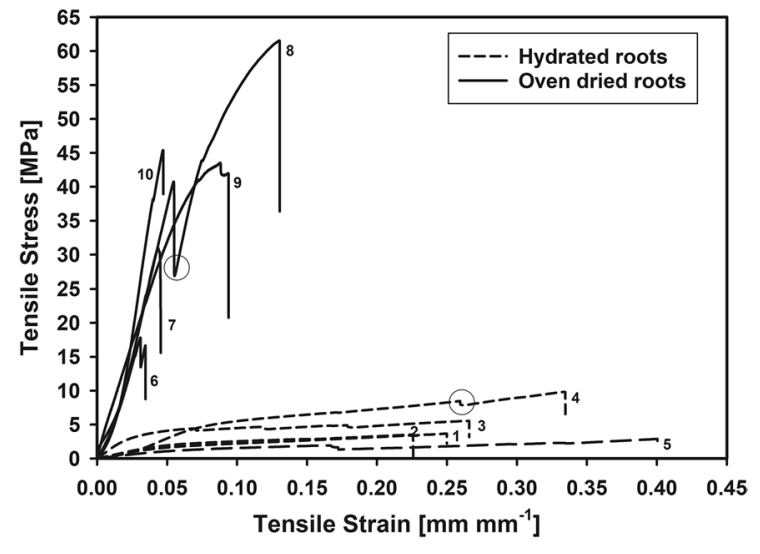

Fig. 1 Typical tensile stress versus tensile strain curves for hydrated root samples (dashed lines) and oven-dried root samples (solid lines). The circles highlight the cortex failure. The tensile strength of dry roots is calculated using the final diameter (i.e., after oven-dried). The roots are number 1 to 10 , and their diameter, tensile strength, Young's modulus and strain at failure are given in Supplementary Table 1

$($ mean $=43.87 \pm 4.07 \mathrm{MPa})$ respectively (Table 1$)$. Both tensile strength and Young's modulus increased with increasing air-drying time. After $30 \mathrm{~min}$ and 60 min air-drying, maximum recorded tensile strength was $25.26 \mathrm{MPa}($ mean $=10.59 \pm 1.16 \mathrm{MPa})$ and $33.93 \mathrm{MPa}($ mean $=16.11 \pm 1.72 \mathrm{MPa})$, respectively (Table 1). The mean tensile strength of the roots tested after $30 \mathrm{~min}$ and $60 \mathrm{~min}$ air-drying were respectively $31 \%$ and $156 \%$ greater than that of hydrated roots (i.e., time 0 ). Mean tensile strength of the roots tested after 60 min was $40 \%$ greater than those tested after $30 \mathrm{~min}$. The Young's modulus of the roots also increased with drying time, with maximum values of $214.52 \mathrm{MPa}($ mean $=95.93 \pm 9.37 \mathrm{MPa})$ and $352.57 \mathrm{MPa}$ (mean $=142.57 \pm 20.97 \mathrm{MPa}$ ) for $30 \mathrm{~min}$ and $60 \mathrm{~min}$ air-drying, respectively (Table 1). When compared with roots at Time 0 , the mean Young's modulus increased by $107 \%$ and $188 \%$ after $30 \mathrm{~min}$ and $60 \mathrm{~min}$ air-drying respectively. The mean Young's modulus of the roots tested after $60 \mathrm{~min}$ was $36 \%$ greater than that measured after $30 \mathrm{~min}$ air-drying.

The relations between root biomechanical properties (tensile strength and Young's modulus) and diameter were fitted using the negative power model commonly reported in literature (Fig. 2). The strength of relations between biomechanical properties and diameter increased with increasing air-drying period 
Tensile Strength
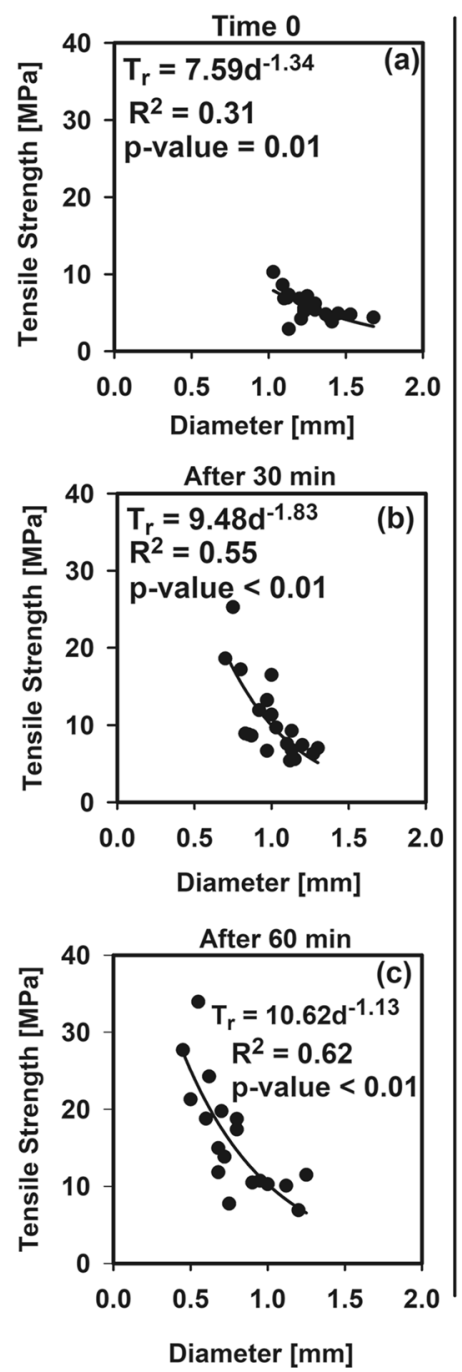

Young's Modulus
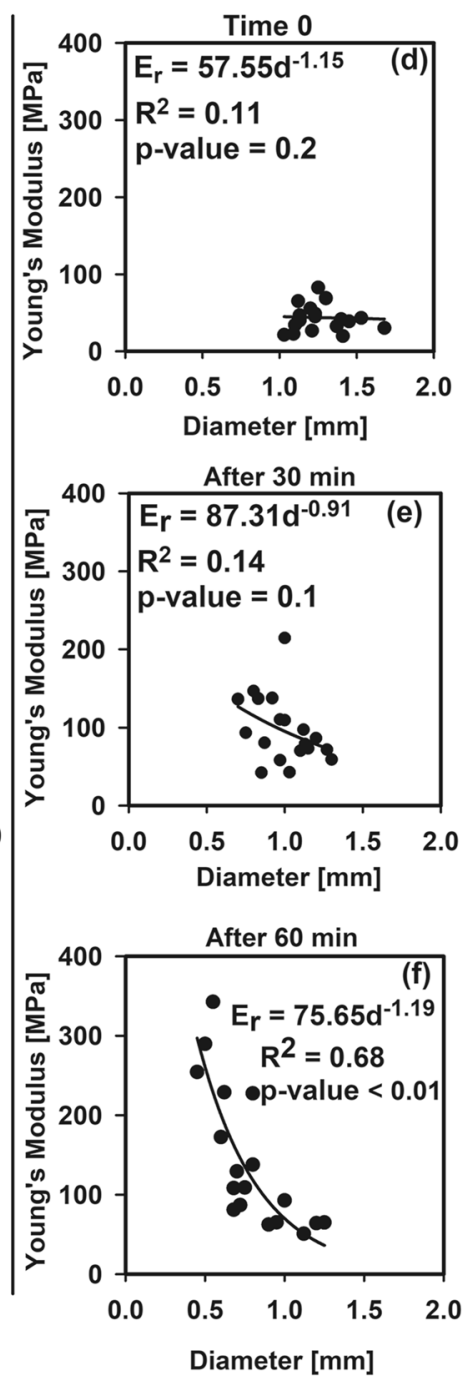
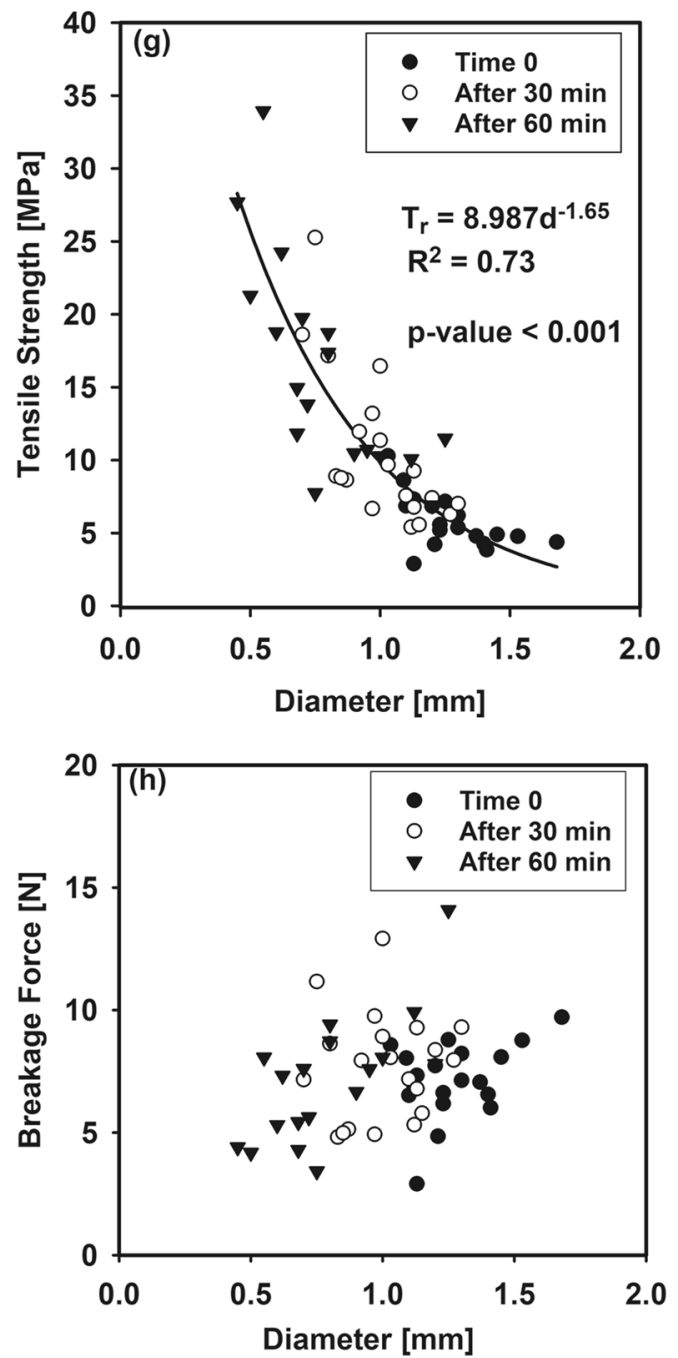

Fig. 2 Root biomechanical properties plotted against final diameter (i.e., after treatment). Tensile strength versus diameter relation for (a) fully hydrated roots at time 0 ; after $30 \mathrm{~min}$ drying; (c) after 60 min drying. Young's modulus versus diameter relation for (d) fully hydrated roots at time 0; (e) After 30 min drying; (f) After 60 min drying. (g) Re-plot of figures a-f combing all treatments; (h) Root breakage force plotted against final diameter (i.e., after treatment) combining all treatments. Lines represent the best fitted curves. Equations, coefficient of determination $\left(\mathrm{R}^{2}\right)$ and $\mathrm{p}$ value for fitted models are given in figure as indicated by the coefficient of determination $\left(\mathrm{R}^{2}\right)$ values. Unlike the tensile strength, the root Young's modulus showed no significant relation with the diameter in hydrated roots (time 0 ) and after $30 \mathrm{~min}$ air-drying. However, after $60 \mathrm{~min}$ air-drying, a strong negative power relation between root Young's modulus and diameter $\left(\mathrm{R}^{2}=0.62 ; \mathrm{p}\right.$ value $\left.<0.001 ; \mathrm{n}=18\right)$ was observed with an abrupt increase of stiffness in thin roots (Fig. 2f). Figure $2 \mathrm{~g}$ replots the tensile strength data to highlight the strength-diameter relation when testing a population of roots varying in water content. Although, there was a significant negative power relation between tensile strength and diameter (Fig. 2g; $\mathrm{R}^{2}=0.73 ; \mathrm{p}$ value $<0.001 ; \mathrm{n}=57$ ), we did not find any relation between the root breakage force and diameter (Fig. 2h). 
Table 1 Summary of number of tested samples, root diameter range, breaking force, tensile strength, Young's modulus and strain at failure for each treatment (time 0 (hydrated roots); after $30 \mathrm{~min}$ air-drying; after $60 \mathrm{~min}$ air-drying)

\begin{tabular}{|c|c|c|c|c|c|c|}
\hline Treatment & $\begin{array}{l}\text { Number } \\
\text { of root } \\
\text { samples }\end{array}$ & $\begin{array}{l}\text { Diameter range } \\
{[\mathrm{mm}]}\end{array}$ & $\begin{array}{l}\text { Breakage force }[\mathrm{N}] \\
{[\text { Mean } \pm S E(\max } \\
\text { value })]\end{array}$ & $\begin{array}{l}\text { Tensile strength } \\
{[\mathrm{MPa}][\mathrm{Mean} \pm S E} \\
(\max \text { value })]\end{array}$ & $\begin{array}{l}\text { Young's Modulus } \\
{[\mathrm{MPa}][\mathrm{Mean} \pm S E} \\
\text { (max value)] }\end{array}$ & $\begin{array}{l}\text { Strain at failure }[\mathrm{mm} \\
\left.\mathrm{mm}^{-1}\right][\text { Mean } \pm S E \\
\text { (max value) }]\end{array}$ \\
\hline Time 0 & 19 & $1.09-1.68$ & $7.15 \pm 0.39(9.71)$ & $5.81 \pm 0.41(10.29)$ & \multicolumn{2}{|c|}{$43.87 \pm 4.07(82.77) 0.30 \pm 0.04(0.36)$} \\
\hline $30 \mathrm{~min}$ & 20 & $1.10-1.76$ & $7.72 \pm 0.49(12.92)$ & $10.59 \pm 1.16(25.26)$ & $\begin{array}{l}95.93 \pm 9.37 \\
(214.52)\end{array}$ & $0.30 \pm 0.01(0.42)$ \\
\hline $60 \mathrm{~min}$ & 18 & $1.00-1.95$ & $7.10 \pm 0.61(14.08)$ & $16.11 \pm 1.72(33.93)$ & $\begin{array}{l}142.57 \pm 20.97 \\
(352.57)\end{array}$ & $0.33 \pm 0.01(0.39)$ \\
\hline
\end{tabular}

Average data are given \pm standard error. Maximum value for each variable is given in parenthesis after the average value. In the case of any slippage, tensile test was discarded ( 1 sample in time 0 treatment; 2 samples in 60 min air-drying treatment)

Tensile strength values did not significantly differ between treatments when calculated using the initial diameters (diameter before treatment) with average values of $5.81 \pm 0.41 \mathrm{MPa}$ (time 0 ); $5.59 \pm 0.39 \mathrm{MPa}$ (after $30 \mathrm{~min}$ drying) and $5.65 \pm 0.40 \mathrm{MPa}$ (after 60 min drying). Similarly, Young's modulus did not significantly differ when calculated using the initial (i.e., before air-drying) diameter of samples (time 0: $43.87 \pm 4.07 \mathrm{MPa}$; after $30 \mathrm{~min}: 51.94 \pm 4.83 \mathrm{MPa}$; after 60 min $45.91 \pm 4.44 \mathrm{MPa}$; Fig. 3). However, the mean root tensile strengths calculated using the final diameters of the roots (i.e., after drying) were $90 \%$ and $184 \%$ greater than the tensile strength obtained using the initial diameters for $30 \mathrm{~min}$ and $60 \mathrm{~min}$ treatment, respectively (Fig. 3). While there was no significant difference between treatments, when the root tensile strength and Young's modulus were calculated using the initial diameters $\left(T_{r}: \mathrm{p}\right.$ value $=0.92 ; E_{r}: \mathrm{p}$ value $=0.41 ;$ Fig. 3$)$, there was a significant difference between treatments in terms of tensile strength and Young's modulus when the final (i.e., after treatment) diameters were used in the calculations $\left(T_{r}\right.$ : $\mathrm{p}$ value $<0.001 ; E_{r}$ : $\mathrm{p}$ value $<0.001$; $\log$ transformed data; Fig. 3).

Root water loss and water content

Root water loss increased with drying time. However, water loss rate was largely influenced by root diameter with thin roots drying faster than thicker roots (Fig. 4). For instance, after $30 \mathrm{~min}$ air-drying, the thinnest root $\left(w_{L}=0.46 \mathrm{~g} \mathrm{~g}^{-1}\right)$ lost 2.3-times more water than the thickest root $\left(w_{L}=0.20 \mathrm{~g} \mathrm{~g}^{-1}\right)$. After 60 min of drying the water loss increased to between $0.69 \mathrm{~g} \mathrm{~g}^{-1}$ and $0.23 \mathrm{~g} \mathrm{~g}^{-1}$ recorded in the smallest and largest diameter roots, respectively (Fig. 4).
At time 0 (hydrated root) water content ranged from $0.72 \mathrm{~g} \mathrm{~g}^{-1}$ to $0.92 \mathrm{~g} \mathrm{~g}^{-1}$, recorded in roots with
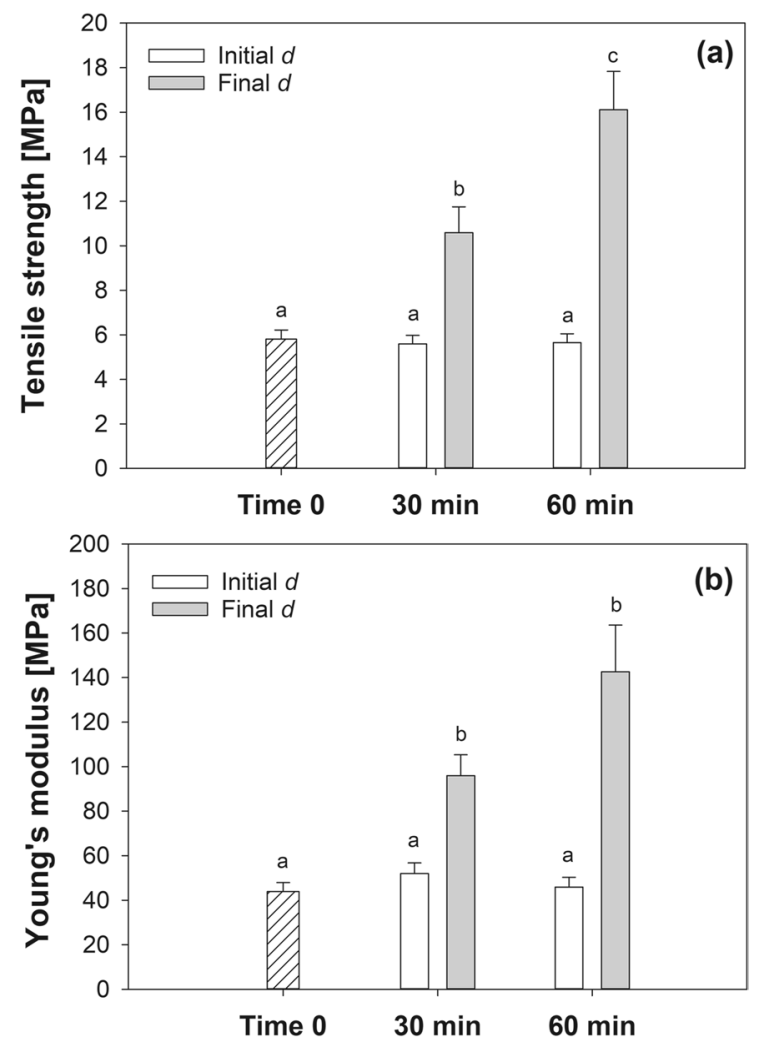

Fig. 3 Mean ( \pm standard error) of (a) tensile strength and (b) Young's modulus calculated using initial diameter (i.e., before air-drying; white bars) and final diameter (i.e., after air-drying; grey bars). Mean ( \pm standard error) of time 0 (hydrated roots) given by the white bar with oblique pattern. Letters indicate a statistically significant difference between treatments, as tested using one-way ANOVA followed by post hoc Tukey's test. Data were log-transformed in statistical analyses of tensile strength and Young's modulus calculated with final diameter 
Fig. 4 Root water loss and water content plotted against initial diameter (diameter of hydrated roots before treatments). Root water loss-diameter relation with the corresponding best fit equation and $\mathrm{R}^{2}$ value for (a) $30 \mathrm{~min}$; (b) $60 \mathrm{~min}$ air-drying. Water loss is defined as $g$ of water loss per $g$ of root fresh weight (hydrated root).

Root water content versus initial diameter for (c) fully hydrated root at time $0 ;(\mathbf{d})$ after $30 \mathrm{~min}$ and (e) $60 \mathrm{~min}$ air-drying. Water content is defined as $g$ of water per $g$ of fresh root material $\underline{\text { Root Water Loss }}$
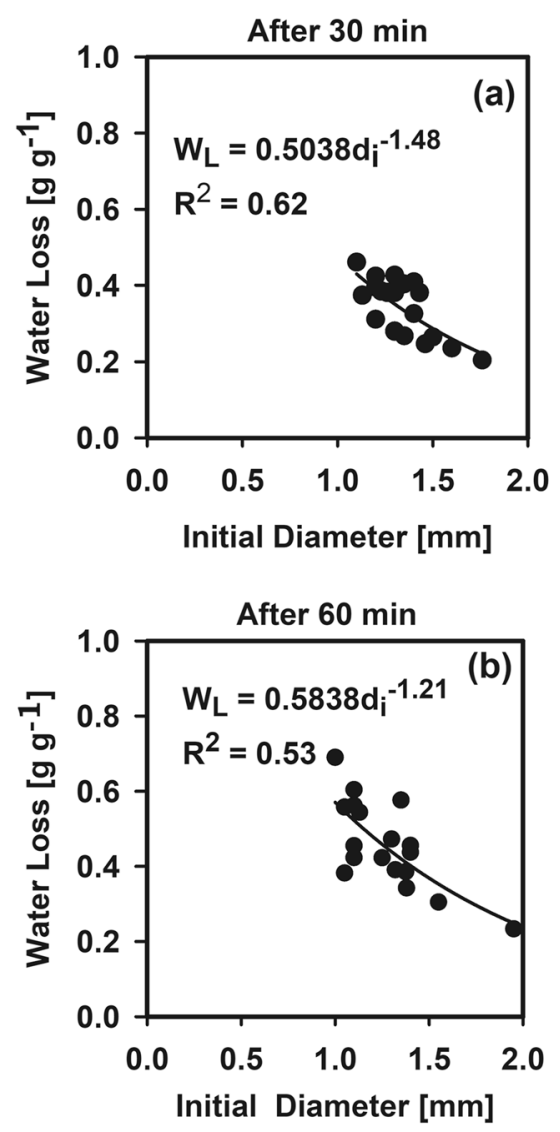

Root Water Content
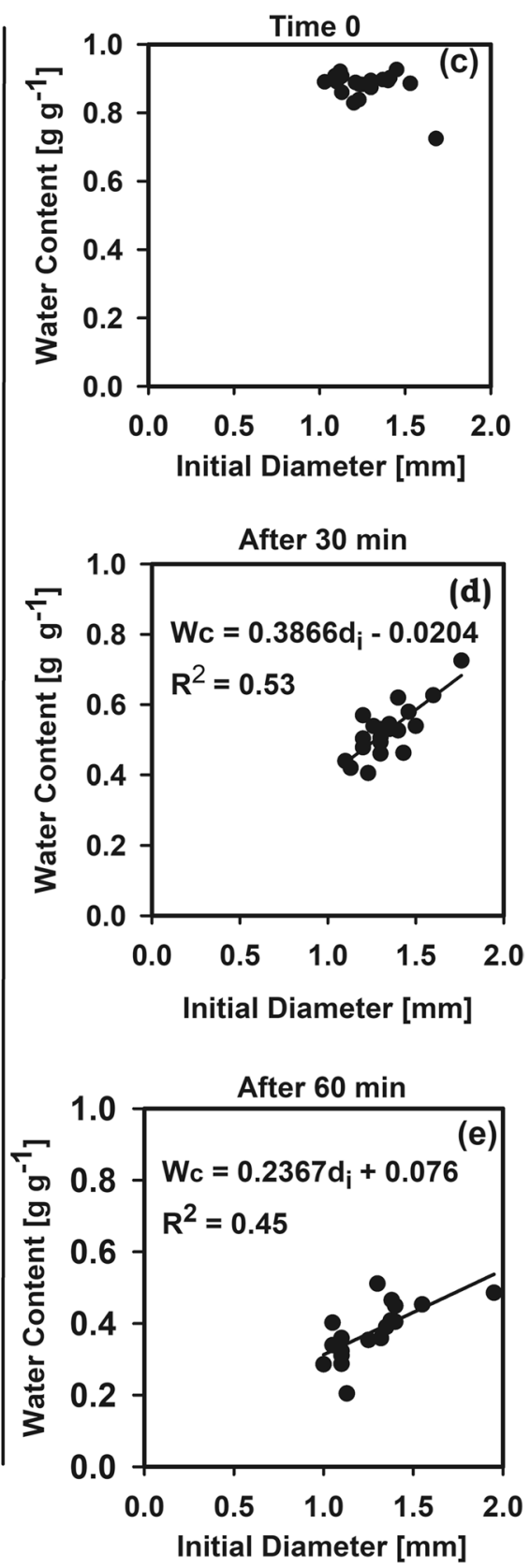

$1.12 \mathrm{~mm}$ and $1.68 \mathrm{~mm}$ diameter, respectively. Therefore, water content constituted up to $92 \%$ of total root weight. After $30 \mathrm{~min}$ air-drying, thin $(<1.30 \mathrm{~mm})$ roots highlighted a notable water loss with water content dropping down to $0.40 \mathrm{~g} \mathrm{~g}^{-1}$ (recorded in a $1.23 \mathrm{~mm} d$ root). In contrast thicker roots lost less water and maintained water content close to fully hydrated values (e.g., $0.73 \mathrm{~g} \mathrm{~g}^{-1}$ in $1.76 \mathrm{~mm}$ root; Fig. 4). After 60 min air-drying, the water content of roots dropped below $60 \%\left(0.20-0.51 \mathrm{~g} \mathrm{~g}^{-1}\right)$. While no relation between root diameter and water content was observed in fully hydrated roots (Fig. 4c), after $30 \mathrm{~min}$ and $60 \mathrm{~min}$, root water content and initial diameter showed a positive relation (Fig. 4d, e). 
Root water loss and root surface area/volume ratio highlighted a positive linear correlation for both drying treatments (Fig. 5). Therefore, root water loss increased with the increase in the root surface area/ volume ratio. The root surface area/volume ratio is inversely proportional to the root diameter and hence thin roots have higher surface area/volume ratio, and water loss, when compared to thicker root.

Root tensile strength and Young's modulus increased with decreasing water content. We observed an abrupt increase of both tensile strength and Young's modulus when root water content dropped below $0.7 \mathrm{~g} \mathrm{~g}^{-1}$ (Fig. 6). Moreover, the root drying increased the variability of biomechanical properties (i.e., scattered data; Fig. 6).

\section{Discussion}

This study has highlighted the influence of short periods of air-drying (e.g., $30 \mathrm{~min}$ ) on both tensile strength and Young's modulus of fibrous roots. F. arundinacea roots became stronger and stiffer when water content dropped below $0.7 \mathrm{~g} \mathrm{~g}^{-1}$ (Fig. 6). Root drying and the change in biomechanical properties were diameter dependent with drying treatments resulting in decreased root diameter and therefore increasing tensile strength. Large tensile strength and Young's modulus values were measured in thin roots that dried faster, and root diameters decreased more, compared with thicker roots (Figs. 4 and 5).
Fig. 5 Root water loss plotted against root surface area/volume ratio after (a) 30 min air-drying and (b) 60 min air-drying
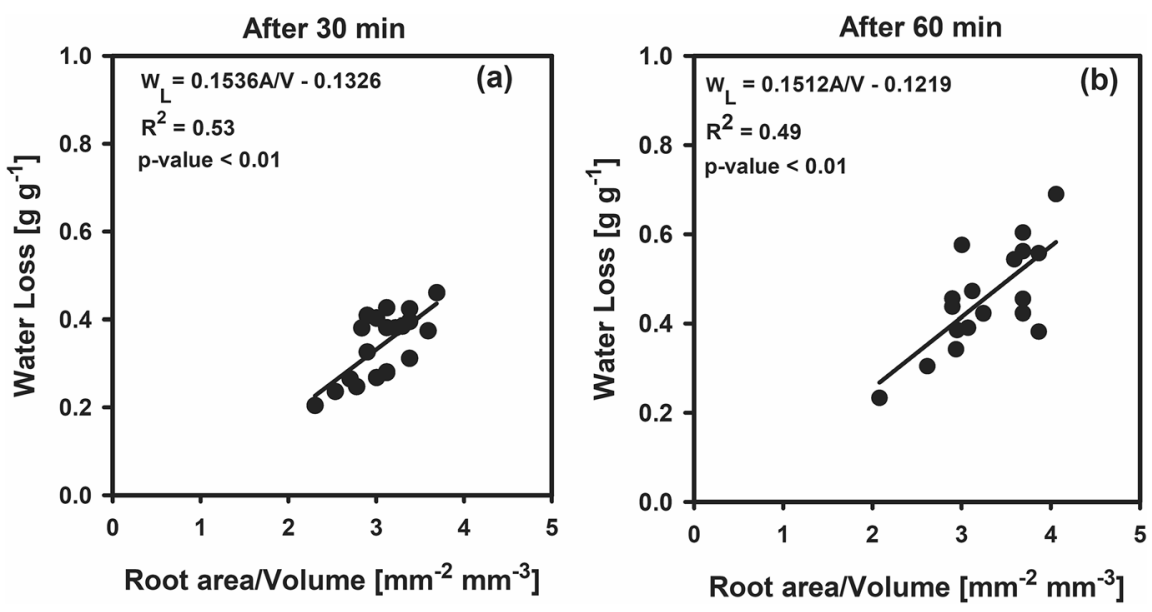

Fig. 6 Root tensile strength (a) and Young's modulus (b) plotted against root water content. Data from all the treatments are included. Tensile strength and Young's modulus are calculated using diameter after treatment. Lines represent the negative power-law curve fitting
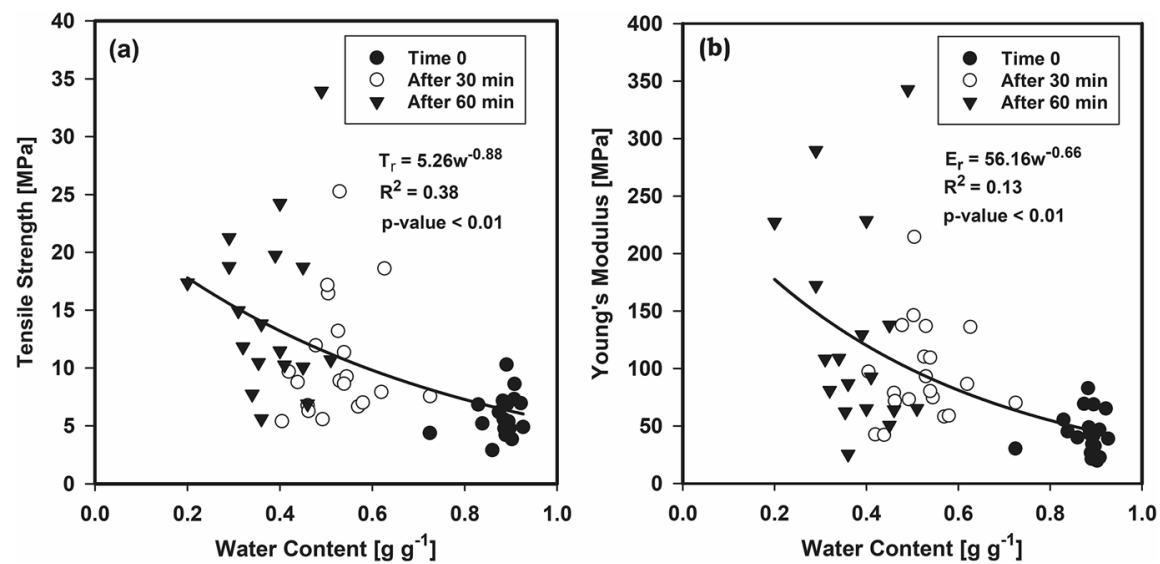
Biomechanical properties and root drying

Hydrated roots of $F$. arundinacea can be considered relatively weak if compared to literature data on fibrous roots for different grass species (Comino et al. 2010; De Baets et al. 2008; Zhang et al. 2019). For instance, Comino et al. (2010) reported strength values up to $372.04 \mathrm{MPa}$ (root $d$ : $0.10 \mathrm{~mm}$ ) for Festuca pratensis. However, extreme strength values (e.g., $>200 \mathrm{MPa})$ found in the literature on grass roots were generally observed in roots thinner than $0.2 \mathrm{~mm}$ (De Baets et al. 2008; Comino et al. 2010). In the present study, the diameter of the tested roots ranged between 0.85 and $1.68 \mathrm{~mm}$ (fully hydrated). Moreover, while root water content and its influence on biomechanical properties were recorded in this study, there is no information about the water status of similar species tested in literature.

Tensile stress-strain curves of roots were strongly affected by oven-drying in the pilot experiment. The oven-dried roots showed smaller strain (i.e., extension) when compared with the completely hydrated roots in agreement with stress-strain curves for woody roots in Boldrin et al. (2018) and Yang et al. (2016). However, short air-drying time (i.e., $30 \mathrm{~min}$ and $60 \mathrm{~min}$ ) did not significantly affect the tensile strain of tested fibrous roots when compared with the hydrated roots.

As expected, the drying method (i.e., oven vs airdrying) highlighted a notable effect on biomechanical properties, with oven-drying (pilot test) leading to two-fold greater maximum strength and Young's modulus values compared with the air-dried treatments. However, it should be highlighted that ovendrying represents an extreme condition, where roots are fully de-hydrated. The maximum values of both tensile strength and Young's modulus for the air-dried roots were recorded after $60 \mathrm{~min}$ air-drying. The increase in root tensile strength and Young's modulus observed after the air-drying period (Fig. 2), is in agreement with the results obtained by previous studies (Boldrin et al. 2018; Hales et al. 2013; Hales and Miniat 2017; Kurowski et al. 2018; Yang et al. 2016; Zhang et al. 2019). In particular, Zhang et al. (2019) observed that the root strength of the herbaceous species Heteropappus altaicus and Poa sphondylodes increased respectively by $27 \%$ and $15 \%$ after $6 \mathrm{~h}$ air-drying. In contrast with our study, Yang et al. (2016) and Mahannopkul and Jotisankasa (2019) reported a decrease in tensile strength after drying. However, these studies tested different plant species (e.g., woody species in Yang et al. (2016)), as well as very different drying treatments in terms of time and method (e.g., chamber with suction control by hanging water column in Mahannopkul and Jotisankasa (2019)). Few studies have evaluated the effect of root drying on Young's modulus. The Young's modulus of non-woody roots of Cicer arietinum increased up to 35-times due to air-drying (Kurowski et al. 2018). In the present study, root tensile strength and Young's modulus increased when the root water content dropped below $0.7 \mathrm{~g} \mathrm{~g}^{-1}$ (Fig. 6). For woody roots of Ulex europaeus, Boldrin et al. (2018) observed a similar increase when the root water content dropped below $0.5 \mathrm{~g} \mathrm{~g}^{-1}$.

A significant decrease in root diameter occurred due to root air-drying ( $\mathrm{p}$ value $<0.001$ ) in agreement with the literature (Boldrin et al. 2017; 2018; Carminati et al. 2013, 2009; Zhang et al. 2019). Since the root tensile strength and Young's modulus are a function of root diameter, changes in these biomechanical properties with drying could be explained by decreases in root diameter. Changes in root tensile strength and Young's modulus in drying treatments were driven by the shrinkage of the roots, because these biomechanical properties are computed by dividing a root breaking force by the corresponding root cross-sectional area (Eqs. 4 and 5). Therefore, in our study, changes in biomechanical properties resulted from a "calculation effect" rather than intrinsic changes of material mechanical properties. Indeed, while there was a significant difference in biomechanical properties between treatments when the final diameter (i.e., after drying treatment) was used in the calculation, there was no significant difference between the tensile strength and Young's modulus across the different treatments when initial diameter (i.e., before air-drying) was used. Moreover, this result was further reinforced by the lack of a significant difference between the breakage forces of the roots subjected to different treatments ( $p$ value $=0.68$ ). A similar conclusion was reported for woody roots upon drying by Boldrin et al. (2018). It should be noted however that woody roots in Boldrin et al. (2018) were air-dried up to $24 \mathrm{~h}$ with notable biomechanical changes recorded after only $5 \mathrm{~h}$ air-drying, despite notable water loss and diameter shrinkage being recorded after only $30 \mathrm{~min}$ in thin 
roots (Boldrin et al. 2018). Although both fibrous and woody roots were mechanically affected by moisture loss, fibrous roots responded faster (i.e. $30 \mathrm{~min}$ vs $>5 \mathrm{~h}$ ). However, in previous studies on non-woody roots, short air-drying periods $(<5 \mathrm{~h})$ were not considered (e.g., 6 or $12 \mathrm{~h}$ in Zhang et al. (2019)). It can be hypothesized that the absence of secondary tissues (e.g., secondary xylem in stele) in grass roots translated in a greater mechanical susceptibility to moisture changes. In particular, initial water loss and diameter shrinkage in woody roots may be limited to cortical and bark tissues (e.g., periderm and senescent cortex), which are known to have negligible mechanical contribution in woody roots (Hathaway and Penny, 1975). The larger cortex to stele ratio of fibrous roots, compared with woody roots (Wang et al. 2019), may result in more shrinking and swelling given the susceptibility of cortical tissues to moisture variation (Berry and Roderick, 2005; Gall et al. 2002). For instance, seasonal and diurnal variation in root water status could significantly affect diameter of roots growing in soil. Huck et al. (1970) noted that root diameters of Gossypiwn hirsutum (cotton), observed in a rhizotron during sunny days, could decrease by up to $40 \%$ in diameter compared to wetter days. More recently, X-ray CT imaging of roots during soil dry/wetting cycles showed that roots shrink as consequence of plant water stress and then continue to shrink in a chain reaction due to the loss of hydraulic conductivity between soil and the root (Carminati et al. 2013). In this regard, root biomechanical properties may vary through changes in root diameter because of transpiration, soil water availability and evaporative demand. Zhang et al. (2019) observed a significant difference between the root tensile strength after sampling (i.e., equilibrated with plant and soil water status) and after full saturation in the laboratory. Significant biomechanical differences were found between root sections tested after being buried in soils differing in water content (Boldrin et al. 2018). It is possible to hypothesize that root drying in soil depends on soil texture, with dry fineparticle soils (e.g., clay soil) inducing more negative water potential at the root surface and hence greater potential to pull water from the root (i.e., drying) than dry coarse-particle soils (e.g., sand; Boldrin et al. 2018). With such complex processes driving root water content it could be necessary to saturate sampled roots before tensile testing to obtain a consistent root hydration status between samples and represent a worst-case scenario for slope stability, as slopes fail with increasing soil moisture and loss of matric suction (Sidle and Bogaard 2016).

Root drying effect on the relation between diameter and biomechanical properties

Negative power law relationships between root biomechanical properties and diameter have been commonly reported, or assumed, in soil bioengineering literature (Comino et al. 2010; De Baets et al. 2008; Mao et al. 2012; Mickovski et al. 2009). However, in this study, the negative power relation was only observed after the air-drying treatments. The hydrated roots (i.e., time 0) showed weak relationships between diameter and both tensile strength and Young's modulus. The development of a negative power law between strength and diameter was highlighted by the increase in the coefficient of determination $\left(\mathrm{R}^{2}\right)$ as drying progressed and strength increased in the thin roots. On the other hand, the strength of the relationship between Young's modulus and diameter increased only after 60 min air-drying $\left(R^{2}\right.$ from 0.11 in hydrated roots to 0.68 after $60 \mathrm{~min}$ air-drying; Fig. 2). Unlike the Young's modulus of fibrous roots tested in our study, the increase in Young's modulus of woody roots tested by Boldrin et al. (2018) occurred only after $24 \mathrm{~h}$ drying and the coefficient of determination of the negative power relationship remained small $\left(\mathrm{R}^{2}=0.24\right)$. It should be noted that woody and herbaceous roots differ in terms of fineroot $(<2 \mathrm{~mm})$ function and structure (e.g., absorptive vs transport roots). While in woody plants absorptive roots may represent from 10 to $58 \%$ of fine roots, in herbaceous plants (e.g., grasses) those account from 60 to $100 \%$ of fine roots (McCormack et al. 2015). The transition from absorptive to transport function in roots is associated with secondary development within the root, including the formation of a waterimpermeable cork periderm, thickening of cell walls, and deposition of suberin in root tissues (Steudle and Peterson 1998). Together, these changes reduce the radial movement of water across root tissues and limit water loss when roots are in contact with dry soil or air-dried in laboratory condition.

When roots from all three treatments were combined, the negative power relation between root tensile strength and diameter highlighted a strong negative 
power relationship $\left(\mathrm{R}^{2}=0.73\right)$. This may be a common condition when tested roots are sampled from plants differing in water status or exposed to laboratory conditions for different periods of time prior to testing. The empirical coefficients of the negative power equation obtained fitting the data of $30 \mathrm{~min}$ $(\alpha=9.48 ; \beta=-1.83)$ and 60 min $(\alpha=10.62$; $\beta=-1.19)$ air-drying treatments were similar to those reported by De Baets et al. (2008) for Helictotrichon filifoluim $(\alpha=14.51 ; \beta=-1.08)$ and Piptatherum miliaceum $(\alpha=11.49 ; \beta=-1.77)$ grasses. However, coefficients of the negative power relationships between strength and diameter largely vary in the literature on fibrous roots (e.g., Lygeum spartum ( $\alpha=60$ $; \beta=-1.30)$ in Mattia et al. (2005); Vetiveria zizanioides $(\alpha=3.30 ; \beta=-1.31)$ in Mickovski and van Beek (2009); Lolium perenne ( $\alpha=1.93 ; \beta=-2.10$ ) in Comino et al. (2010)). Additionally, in fibrous roots, biomechanical properties and their relationship with diameter can vary between seminal, nodal and lateral roots (Loades et al. 2013) further complicating drivers of root biomechanical properties.

In this study, the mechanism enhancing the negative power relation between biomechanical properties and diameter was found to be driven by differences in root water loss and shrinkage across different diameter classes. Thinner roots highlighted faster drying, and greater shrinkage, than larger diameter roots. Root water loss and water content were diameter dependent and inversely related to root surface area/volume ratio (Figs. 4 and 5). For instance, the thinnest root before treatment $(1 \mathrm{~mm})$ had twice the root surface area/volume ratio than the largest root $(1.95 \mathrm{~mm})$. Therefore, thin roots lost water at a faster rate when compared with the large roots. Previous studies obtained similar results for both non-woody (Kurowski et al. 2018) and woody roots (Boldrin et al. 2018).

Our results suggest over relatively short air-drying periods significant water loss can lead to increases in both tensile strength and stiffness of thin roots, exaggerating negative power relationships between biomechanical properties and diameter.

\section{Conclusion}

This study highlighted that short air-drying periods (e.g., $30 \mathrm{~min}$ ) due to root exposition to laboratory conditions can induce notable changes in biomechanical properties of fibrous roots. Although previous studies highlighted the effect of root drying on biomechanical properties, such effects were measured only after relatively long air-drying periods (e.g., $>5$ h) and mainly on woody roots. Water loss and diameter shrinkage, induced by air-drying, were diameter dependent, with thinner roots drying faster than ticker roots due to their larger evaporative surface per volume. This enhanced the negative power law relationship between root diameter and both tensile strength and Young's modulus. Therefore, root drying can lead to the overestimation of strength and stiffness in thin roots. The change of root biomechanical properties after only $30 \mathrm{~min}$ airdrying indicates that care must be taken during root handling and testing to ensure that all the root diameter classes being tested have consistent water content. Our study on fibrous roots supports the statement made by Hales et al. (2013) and Boldrin et al. (2018) for woody roots that laboratory testing of roots must be performed on fully hydrated roots, which likely represents the more conservative (i.e., weaker) condition for both soil on slopes and roots as landslides are generally triggered by heavy precipitation and loss of matric suction (i.e., large soil and root water contents). Under laboratory conditions roots should therefore be fully saturated prior to testing with water content maintained until testing.

Further work is needed to understand the effect of root drying on biomechanical properties in different species with contrasting root anatomy, morphology and adaptation to environment (e.g., drought resistance). Moreover, it should be highlighted that the effect of drying period (e.g., 30 or $60 \mathrm{~min}$ ) depends on laboratory conditions such as temperature and humidity $\left(19{ }^{\circ} \mathrm{C}\right.$ and $50 \%$ in the present study). Indeed, future work is still necessary to find the microscopic mechanisms driving root shrinkage (e.g., intracellular forces driven by water potential drop) and their response to boundary conditions (e.g., vapor pressure deficit in the laboratory during testing or soil moisture during sampling).

Acknowledgements This work at The James Hutton Institute was partly funded by the Rural \& Environment Science \& Analytical Services Division of the Scottish Government. E.C Ekeoma was funded by the Petroleum Technology Development Fund (PTDF). A. G. Bengough and D. Boldrin are also funded by the EPSRC project (EP/R005834/1) "Climate Adaptation Control Technologies for Urban Spaces (CACTUS)". 
Open Access This article is licensed under a Creative Commons Attribution 4.0 International License, which permits use, sharing, adaptation, distribution and reproduction in any medium or format, as long as you give appropriate credit to the original author(s) and the source, provide a link to the Creative Commons licence, and indicate if changes were made. The images or other third party material in this article are included in the article's Creative Commons licence, unless indicated otherwise in a credit line to the material. If material is not included in the article's Creative Commons licence and your intended use is not permitted by statutory regulation or exceeds the permitted use, you will need to obtain permission directly from the copyright holder. To view a copy of this licence, visit http://creativecommons.org/licenses/by/4.0/.

\section{References}

Berry SL, Roderick ML (2005) Plant-water relations and the fibre saturation point. New Phytol 168:25-37. https://doi. org/10.1111/j.1469-8137.2005.01528.x

Bischetti GB, Chiaradia EA, Simonato T, Speziali B, Vitali B, Vullo P, Zocco A (2005) Root strength and root area ratio of forest species in lombardy (northern Italy). Plant Soil 278:11-22. https://doi.org/10.1007/s11104-005-0605-4

Bischetti GB, Chiaradia EA, Epis T, Morlotti E (2009) Root cohesion of forest species in the Italian alps. Plant Soil 324:71-89. https://doi.org/10.1007/s11104-009-9941-0

Boldrin D, Leung AK, Bengough AG (2017) Root biomechanical properties during establishment of woody perennials. Ecol Eng 109:196-206. https://doi.org/10.1016/j.ecoleng. 2017.05.002

Boldrin D, Leung AK, Bengough AG (2018) Effects of root dehydration on biomechanical properties of woody roots of Ulex europaeus. Plant Soil 431:347-369. https://doi. org/10.1007/s11104-018-3766-7

Boldrin D, Bengough AG, Lin Z, Loades KW (2021) Root age influences failure location in grass species during mechanical testing. Plant Soil. https://doi.org/10.1007/ s11104-020-04824-6

Carminati A, Vetterlein D, Weller U, Vogel H, Oswald SE (2009) When roots lose contact. Vadose Zone J 8:805809. https://doi.org/10.2136/vzj2008.0147

Carminati A, Vetterlein D, Koebernick N, Blaser S, Weller U, Vogel HJ (2013) Do roots mind the gap? Plant Soil 367:651-661. https://doi.org/10.1007/s11104-012-1496-9

Comino E, Marengo P, Rolli V (2010) Root reinforcement effect of different grass species: a comparison between experimental and models results. Soil Tillage Res 110:6068. https://doi.org/10.1016/j.still.2010.06.006

De Baets S, Poesen J, Reubens B, Wemans K, De Baerdemaeker J, Muys B (2008) Root tensile strength and root distribution of typical Mediterranean plant species and their contribution to soil shear strength. Plant Soil 305:207-226. https://doi.org/10.1007/s11104-008-9553-0

Docker BB, Hubble TCT (2008) Quantifying root-reinforcement of river bank soil by four Australian tree species. Geomorphology 100:401-418. https://doi.org/10.1016/j. geomorph.2008.01.009

Dong Q, Shuai H, Fei L, Liu L, Wang Z (2019) Interaction between $\mathrm{Cd}$ and $\mathrm{Zn}$ on metal accumulation, translocation and mineral nutrition in tall fescue (Festuca arundinacea). Int J Mol Sci 20(13):3332. https://doi.org/10.3390/ijms2 0133332

Fan CC, Su CF (2008) Role of roots in the shear strength of root-reinforced soils with high moisture content. Ecol Eng 33:157-166. https://doi.org/10.1016/j.ecoleng.2008.02. 013

Gall R, Landolt W, Schleppi P, Michellod V, Bucher JB (2002) Water content and bark thickness of Norway spruce (Picea abies) stems: phloem water capacitance and xylem sap flow. Tree Physiol 22:613-623. https://doi.org/10. 1093/treephys/22.9.613

Genet M, Stokes A, Salin F, Mickovski SB, Fourcaud T, Dumail JF, Van Beek R (2005) The influence of cellulose content on tensile strength in tree roots. Plant Soil 278:19. https://doi.org/10.1007/s11104-005-8768-6

Ghestem M, Veylon G, Bernard A, Vanel Q, Stokes A (2014) Influence of plant root system morphology and architectural traits on soil shear resistance. Plant Soil 377:43-61. https://doi.org/10.1007/s11104-012-1572-1

Giadrossich F, Schwarz M, Cohen D, Cislaghi A, Vergani C, Hubble T, Phillips C, Stokes A (2017) Methods to measure the mechanical behaviour of tree roots: a review. Ecol Eng 109:256-271. https://doi.org/10.1016/j.ecoleng.2017. 08.032

Gibson DJ, Newman JA (2001) Festuca arundinacea Schreber (F. elatior L. ssp. arundinacea (Schreber) Hackel). J Ecol 89:304-324. https://doi.org/10.1046/j.1365-2745.2001. 00561.x

Hales TC, Miniat CF (2017) Soil moisture causes dynamic adjustments to root reinforcement that reduce slope stability. Earth Surf Process Landf 42:803-813. https://doi.org/ 10.1002/esp.4039

Hales TC, Ford CR, Hwang T, Vose JM, Band LE (2009) Topographic and ecologic controls on root reinforcement. J Geophys Res Earth Surf 114:F03013. https://doi.org/10. 1029/2008JF001168

Hales TC, Cole-Hawthorne C, Lovell L, Evans SL (2013) Assessing the accuracy of simple field-based root strength measurements. Plant Soil 372:553-565. https://doi.org/10. 1007/s11104-013-1765-2

Hathaway RL, Penny D (1975) Root strength in some populus and Salix clones. New Zeal J Bot 13:333-344. https://doi. org/10.1080/0028825X.1975.10430330

Huck MG, Klepper B, Taylor HM (1970) Diurnal variations in root diameter. Plant Physiol 45:529-530

Jotisankasa A, Taworn D (2016) Direct shear testing of clayey sand reinforced with live stake geotechnical. Testing Journal. https://doi.org/10.1520/gtj20150217

Khashij S, Karimi B, Makhdoumi P (2018) Phytoremediation with Festuca arundinacea: a mini review. Int J Health Life Sci 4(2):e86625. https://doi.org/10.5812/ijhls.86625

Kim JH, Fourcaud T, Jourdan C, Maeght JL, Mao Z, Metayer J, Meylan L, Pierret A, Rapidel B, Roupsard O, de Rouw A, Sanchez MV, Wang Y, Stokes A (2017) Vegetation as a driver of temporal variations in slope stability: the impact of hydrological processes. Geophys Res Lett 44:48974907. https://doi.org/10.1002/2017GL073174

Kurowski P, Vautrin C, Genet P, Hattali P, Peralta y Fabi R, Kolb E (2018) Mechanical properties of drying plant roots: Evolution of the longitudinal Young's modulus of 
chick-pea roots with dessication. Soft Condensed Matter. https://doi.org/10.13140/RG.2.230782.59200

Liang T, Bengough AG, Knappett JA, MuirWood D, Loades KW, Hallett PD, Boldrin D, Leung AK, Meijer GJ (2017) Scaling of the reinforcement of soil slopes by living plants in a geotechnical centrifuge. Ecol Eng 109:207-227. https://doi.org/10.1016/j.ecoleng.2017.06.067

Loades KW, Bengough AG, Bransby MF, Hallett PD (2013) Biomechanics of nodal, seminal and lateral roots of barley: effects of diameter, waterlogging and mechanical impedance. Plant Soil 370:407-418. https://doi.org/10. 1007/s11104-013-1643-y

Loades KW, Bengough AG, Bransby MF, Hallett PD (2015) Effect of root age on the biomechanics of seminal and nodal roots of barley (Hordeum vulgare L.) in contrasting soil environments. Plant Soil 395:253-261. https://doi. org/10.1007/s11104-015-2560-z

Mahannopkul K, Jotisankasa A (2019) Influence of root suction on tensile strength of Chrysopogon zizanioides roots and its implication on bio-slope stabilization. J Mt Sci 16(2):275-284. https://doi.org/10.1007/ s11629-018-5134-8

Mao Z, Saint-André L, Genet M, Mine FX, Jourdan C, Rey H, Courbaud B, Stokes A (2012) Engineering ecological protection against landslides in diverse mountain forests: choosing cohesion models. Ecol Eng 45:55-69. https:// doi.org/10.1016/j.ecoleng.2011.03.026

Mao Z, Wang Y, McCormack ML, Rowe N, Deng X, Yang X, Xia S, Nespoulous J, Sidle RC, Guo D, Stokes A (2018) Mechanical traits of fine roots as a function of topology and anatomy. Ann Bot. https://doi.org/10.1093/aob/ mcy076

McCormack ML, Dickie IA, Eissenstat DM, Fahey TJ, Fernandez CW, Guo D, Helmisaari HS, Hobbie EA, Iversen CM, Jackson RB, Leppälammi-Kujansuu J, Norby RJ, Phillips RP, Pregitzer KS, Pritchard SG, Rewald B, Zadworny M (2015) Redefining fine roots improves understanding of below-ground contributions to terrestrial biosphere processes. New Phytol 207:505-518. https://doi.org/10.1111/ nph. 13363

Mattia C, Bischetti GB, Gentile F (2005) Biotechnical characteristics of root systems of typical Mediterranean species. Plant Soil 278:23-32. https://doi.org/10.1007/ s11104-005-7930-5

Mickovski SB, van Beek LPH (2009) Root morphology and effects on soil reinforcement and slope stability of young vetiver (Vetiveria zizanioides) plants grown in semi-arid climate. Plant Soil 324:43-56. https://doi.org/10.1007/ s11104-009-0130-y

Mickovski SB, Hallett PD, Bransby MF, Davies MCR, Sonnenberg R, Bengough AG (2009) Mechanical reinforcement of soil by willow roots: impacts of root properties and root failure mechanism. Soil Sci Soc Am J 73:1276-1285. https://doi.org/10.2136/sssaj2008.0172

Norris JE, Di Iorio A, Stokes A, Nicoll BC, Achim A (2008) Species selection for soil reinforcement and protection.
In: Norris JE, Stokes A, Mickovski SB, Cammeraat E, van Beek R, Nicoll BC, Achim A (eds) Slope stability and erosion control: ecotechnological solutions. Springer, Dordrecht, pp 167-210. https://doi.org/10.1007/ 978-1-4020-6676-4

Reinbott TM, Blevins DG (1995) Multiyear use of killed strips for forage and grain sorghum production in a tall fescue pasture. J Prod Agric 8:354-359. https://doi.org/10.2134/ jpa1995.0354

Schwarz M, Lehmann P, Or D (2010) Quantifying lateral root reinforcement in steep slopes-from a bundle of roots to tree stands. Earth Surf Proc Land 35:354-367. https://doi. org/10.1002/esp.1927

Schwarz M, Giadrossich F, Cohen D (2013) Modeling root reinforcement using a root-failure Weibull survival function. Hydrol Earth Syst Sci 17:4367-4377

Schwarz M, Phillips C, Marden M, Mclvor IR, Douglas GB, Watson A (2016) Modelling of root reinforcement and erosion control by 'Veronese' poplar on pastoral hill country in New Zealand. NZ J For Sci 46:4. https://doi.org/10. 1186/s40490-016-0060-4

Sidle RC, Bogaard TA (2016) Dynamic earth system and ecological controls of rainfall-initiated landslides. Earth Sci Rev 159:275-291. https://doi.org/10.1016/j.earscirev. 2016.05.013

Stokes A, Atger C, Bengough AG, Fourcaud T, Sidle RC (2009) Desirable plant root traits for protecting natural and engineered slopes against landslides. Plant Soil 324:1-30. https://doi.org/10.1007/s11104-009-0159-y

Steudle E, Peterson CA (1998) How does water get through roots? J Exp Bot 49:775-788

Wang H, Wang Z, Dong X (2019) Anatomical structures of fine roots of 91 vascular plant species from four groups in a temperate forest in Northeast China. PLoS ONE 14(5):e0215126. https://doi.org/10.1371/journal.pone. 0215126

Wu TH, McKinnell Iii WP, Swanston DN (1979) Strength of tree roots and landslides on price of Wales Island, Alaska. Can Geotech J 16:19-33

Yang Y, Chen L, Li N, Zhang Q (2016) Effect of root moisture content and diameter on root tensile properties. PLoS ONE 11(3):e0151791. https://doi.org/10.1371/journal. pone. 0151791

Zhang CB, Zhou X, Jiang J, Wei Y, Ma J, Hallett PD (2019) Root moisture content influence on root tensile tests of herbaceous plants. CATENA 172:140-147. https://doi. org/10.1016/j.catena.2018.08.012

Publisher's note Springer Nature remains neutral with regard to jurisdictional claims in published maps and institutional affiliations. 